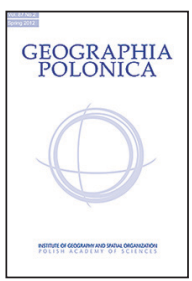

\title{
THE CURZON LINE AS THE EASTERN BOUNDARY OF POLAND: THE ORIGINS AND THE POLITICAL BACKGROUND*
}

\section{Piotr Eberhardt}

Institute of Geography and Spatial Organization

Polish Academy of Sciences

Twarda 51/55, 00-818 Warsaw: Poland

e-mail address: p.ebe@twarda.pan.pl

\begin{abstract}
The paper presents the political history of the present-day eastern boundary of Poland (Polish-Ukrainian and Polish-Belarusian). The respective line was called the Curzon Line due to the initiative of the Foreign Secretary of Great Britain, George Nathaniel Curzon (1859-1925). On December 8th, 1919, he suggested a provisional demarcation line separating Poland from Bolshevik Russia. At that time, it was just one of many proposals for the course of the line of separation and did not play any significant political role. The name, the Curzon Line, was brought back into use during World War II by Stalin and accepted by Roosevelt and Churchill at the conferences in Teheran in 1943 and in Yalta in 1945, as the eastern boundary of Poland. In this article, the causes and consequences of this decision are considered, based on the source documents and the literature on the subject. The political boundary which was forced upon Poland by the three superpowers after the defeat of the German Third Reich, and the inclusion of Poland in the Soviet zone of influence are the subjects of this article.
\end{abstract}

\section{Key words}

Curzon Line - boundary of Poland • political boundary - World War II • historical geography

\section{Introduction}

The eastern boundary of Poland, which exists today, runs along a segment of land between the Carpathian Mts. in the south and the Augustów Canal in the north. The boundary is approximately the same as the socalled Curzon Line. This fact is well-known and is noted in every encyclopaedia and historical reference book. Yet, when this dividing line is considered in a more detailed manner, it turns out that the literature on the subject contains numerous simplifications and distortions. This makes it difficult to understand the reasons and premises for the delimitation of the boundary decided at the meeting of the allied powers in Teheran and then ultimately approved at the conference in Yalta. The decisions of the three allied powers, taken at the end of the World War II, referred in a straightforward manner to the proposals that had already been formulated just after World War I. These proposals were recalled and then implemented 25 years later in completely different geopolitical conditions.
In international politics, until as late as World War I, the possibility of a re-establishment of the Polish state had not been seriously considered. The designs concerning the future boundaries of sovereign Poland were treated as abstract suggestions, far removed from the realities of Europe at that time. The European countries showed a lack of interest in the Polish aspirations for a sovereign statehood. This lack is well evidenced by Europe's reaction to the tsarist's 1912 exclusion of the then newly created governorship of Chełm from the territory of the so-called Polish Kingdom. This territorial change was an obvious violation to the decisions of the Vienna Treaty of 1815. The issue, however, did not even raise much interest from the two other powers which had partitioned Poland (Prussia and Austria). The Poles, on the other hand, reacted quite emotionally to this move of the tsarist administration. Outside of Poland, the issue was considered a question of secondary importance, subject fully to the rule of the Russian authorities (Dymsza 1911).

Polish society was well aware of the realities of the political situation. Poles knew that only a European

\footnotetext{
* The paper has been prepared in the framework of a research project funded by the National Science Center (according to decision no. 2011/01/B/HS4/05903) titled: 
war could cause a change in their situation. Two orientations developed, with hopes for the potential victory of the central powers, or of the Entente Cordiale. The regaining of independence by Poland was, however, a far away dream which was hard to even imagine. Yet, numerous Polish historians, geographers and political activists assumed that this dream would sooner or later come true. When it happens, it would be of utmost importance to establish the boundaries of Poland, which would reappear from political nonexistence.

Throughout the entire 19th century, Poles had clear views about what the territory of the so-called Polish land amounted to. At this time, it was felt the only just and satisfying solution would be to return to the historical boundaries of the Polish-Lithuanian Commonwealth (Rzeczpospolita Obojga Narodów). The idea of restoring the Commonwealth to its 1772 boundaries, i.e. the boundaries from before the first partition of Poland, constituted a program which was obvious and without controversy. Until the turn of the 20th century, the issues of the ethnic, language and religious composition of the territory of the historical Commonwealth were marginalised. There was an awareness of the differences between "the Crown" (Poland), Lithuania and Ruthenia (largely identical with the present-day Ukraine). It was assumed, though, that the centurieslong community of ideas linking the people of the Commonwealth was still in existence, despite the border barriers imposed by the partitioning powers. The regional differences were treated as secondary. Any problems would be resolved without conflict with the potential agreement on a kind of federation. It was expected that the eastern boundary of Poland would be the Dneper and Berezyna rivers, and any other solution would have been regarded as unfair.

The political as well as the demographic and ethnic conditions began to change quickly. The idea of a return to the historical boundaries was becoming less and less obvious. To a lesser extent, this fact was due to external conditions and to a greater extent to the transformations in the consciousness and the attitudes of the population inhabiting the Eastern Borderlands (Kresy) of the Commonwealth. In this territory, new national ideas took shape relatively late. The lower classes were poorly educated and there was a lack of influential local leaders so the peasant tradition persisted. During the several centuries in which the Commonwealth existed, the upper classes underwent Polonization and formed one "noble nation". They were associated with Polish culture and language, and cultivated the tradition of a single unified nation. The national identification option started to take shape gradually in the local peasant populations at the end of the 19th century. When the national identification ideas reached the inhabitants of the Eastern Borderlands, the apparently homogeneous territories between the Bug and Dneper Rivers started to differentiate ethnically. In effect, the territory of the historical Commonwealth got divided up into areas featuring separate ethnicity (Polish, Ukrainian, Ruthenian, Belarusian, Lithuanian, Latvian). The boundaries between the Polish and non-Polish areas were not always quite clear. Wide borderlands existed inhabited by popula- tions having trouble relating to the national self-identification. These difficulties in identification appeared especially there, where the divisions between the religious denominations were not identical with those of the language used.

The educated part of the Polish community and the independence activists started to face a highly significant dilemma which was more political than scientific. Two notions appeared - one of the so-called historical Poland and the other of the so-called ethnic Poland (see also: Wapiński 1994). These two notions differed quite a bit. The leading Polish geographers (Wincenty Pol, Wacław Nałkowski, Eugeniusz Romer) were still convinced the Polish nation had full political rights to the areas situated between ethnic Poland and ethnic Russia. They used historical, social and economic arguments to back up their stances. At that time, the existing eastern boundary of the so-called Polish Kingdom was treated as an artificial barrier, which the tsarist regime had imposed by sheer force. The liquidation of this boundary and the joining of the two territories was thought to be the condition for the compensation of the historical wrong.

In the years preceding the outbreak of World War I, an increasing importance had been assigned to the ethnic aspects and the principles of subjective selfidentification. The shape of the initially quite fragmentary language and religious divisions was becoming increasingly clear. Demographic studies started to appear by Ukrainian, Belarusian and Lithuanian researchers, who questioned the re-establishing of the Commonwealth. As the spokesmen for the aspirations of their respective nations, they criticised the developments and cultural achievements of Poland. In response, educated Poles emphasized the political and social significance of the local Polish population. Serious controversies arose as to the numbers and distribution of the particular nationalities. As an example, the region of Vilna was presented as a Polish, Lithuanian or Belarusian area, depending upon the nationality of the researcher (Kowalski 2008).

The difference between the territorial ranges of 'historical' and 'ethnic' Poland was very important. Those of Polish nationality were condensed in an area that was three or even four times smaller than the territory of the historical Polish-Lithuanian Commonwealth. There started to develop a realization that a return to the boundaries from before the partitions was not realistic in view of the ethnic configurations taking shape. Consequently, the increasingly divergent views had to be taken into consideration concerning the suggested territorial shape of the future, potentially independent Polish territory. Along with the concepts still referring to the eastern boundaries of the Commonwealth, designs began to appear for a relatively smaller national country. These designs described eastern boundaries which would reach the Bug and San Rivers (Bolesław Wysłouch). The idea of giving up of the area of Chełm, mentioned earlier, was even considered (Czesław Jankowski). Usually, though, intermediate territorial programs were formulated. In these programs, it was thought the future Poland would include the ethnically mixed areas where there was a significant number of 
Poles (like western Volhynia and Podole, the regions of Vilna or of Minsk), and the areas situated farther to the east would be given up (see also: Eberhardt 2004).

The outbreak of the World War I again gave rise to the creation of future-oriented concepts. It was expected that the political situation in Central-Eastern Europe would be transformed, which would mean the Polish question would gain international significance. The partitioning powers, for quite obvious pragmatic reasons, started to formulate more or less consistent promises for a small, autonomous or satellite Poland. After the potential victory of the central powers, it was expected the Germans would be inclined to cut off some parts in the west of the Polish Kingdom in exchange for areas which were not well defined, to the east of the Bug River. The Russians saw future Poland within the boundaries of the Russian Empire. Their proposals for the future Polish Kingdom would have Poland gaining territory at the expense of Germany and Austria. Poles started to see the opportunity for liquidating the partitioning barriers and for a unification of the Polish lands. Definite future political boundaries of Poland were becoming more realistic. A number of original concepts were developed by Poles for the boundaries of future Poland (particularly by Włodzimierz Wakar, Wiktor Skarga-Dobrowolski, Adam Szelagowski, or Józef Jaskólski). The concepts differed significantly as to the principles and details, but these concepts were only symbolic since no political forces supported them. The territorial designs that were presented later by Roman Dmowski at the meetings of the peace conference in Versailles, were an entirely different matter. Dmowski's concepts had definite political support. They were being considered by world leaders and played an important political role (Dmowski 1947).

In consequence of the unexpected defeat of all the three partitioning powers, the new Poland was reborn in November 1918. The boundaries of the new state had been taking shape over a period of three years. The boundary with Germany was established in the Treaty of Versailles in June 1919 by the countries of the victorious Entente. The eastern boundary of Poland depended upon the outcome of the unavoidable military conflict between Poland and Bolshevik Russia. The potential defeat of Poland would put an end to Poland's sovereign existence, while the scale of a potential Polish victory could have an important influence on the course of the boundary between the two countries. The possibilities of intervention from western powers were quite limited. The western powers were not interested in a total defeat of Poland, yet they were quite critical of the more maximalist territorial claims from the Polish side. The attitude of the members of the Entente Cordiale toward the issue of the Polish eastern boundary was not fixed. France was more positive towards Polish aspirations and interests. The British, especially Prime Minister David Lloyd George, were definitely more negative and tried to limit the territorial aspirations of the Poles.

\section{The design of the Curzon Line as the eastern boundary of Poland after World War I}

In the final phase of the war, the possibility of re-establishing the Polish state was becoming increasingly realistic. The defeat of the tsarist army and the two Russian revolutions had excluded the eastern occupant from European politics for some time. The new political groups that gained power in Russia, largely consented to the unavoidable loss of the territory of the Polish Kingdom. Starting in 1915, this area had already been occupied by the central armies. The latter, though, were not capable of inflicting defeat upon the Entente. The decisive role in the new European order was to be played by France, Great Britain and the United States. All of the three countries gradually recognised Poland's right to sovereignty, and the right to safe western and eastern boundaries. As the Russian ally declined to continue fighting, the western powers found it easier to formulate the requirements for establishing an independent Poland. The successive declarations issued by the countries of the Entente were increasingly realistic and more widely agreed on. One of the first such declarations was put forward on December 3rd, 1917, and contained the following stipulation: "the establishment of an independent Poland, ensuring its free political and economic development, constitutes one of the preconditions for a persistent and just peace in Europe"1. The subsequent statement of the French Foreign Minister, Stéphane Pinchon, of December 12th, 1917, was very similar in its content: "We wish for an independent Poland with all the guarantees of free political, economic and military development, and all the consequences thereof." Then, David Lloyd George made a declaration on behalf of Great Britain in his speech of January 5th, 1918, saying: "We think that independent Poland, encompassing all the genuinely Polish elements who want to become a part of it, is a pressing need for the stabilisation of Western Europe" (see also classical position in Polish literature: Piszczkowski 1969).

In this statement the expression of "genuinely Polish elements" was underlined, which clearly indicated that the British Prime Minister supported the concept of an 'ethnic' Poland. He remained faithful to this concept later on, consistently proposing what was to be called the Curzon Line as the eastern boundary of Poland.

The subsequent key event is associated with the announcement issued on June 3rd, 1918, at the conference of the three main members of the Entente, that is - France, Great Britain and Italy. At this conference, the establishment of an independent Poland, following victorious war, was announced. The growing political importance of the United States placed President Woodrow Wilson in a very significant position. That is why in August 1918, Dmowski, one of the official political leaders in Poland went to the United States and had a meeting with Ignacy Paderewski and Woodrow Wilson. During this meeting, the Polish territorial 
claims were presented. The most important claim was for free access to the seacoast and that not only the Prussian part of partitioned Poland, but also the fragments of Upper Silesia and East Prussia be included. An outline for the eastern boundary of Poland was also presented. The memorandum was handed over after the meeting. It contained a corresponding map, which specified the territorial demands of the Polish side. This map presented the first version of the so-called Dmowski line. It was suggested that the entire area of Galicia (in the south and south-east) be incorporated into Poland, and that the former eastern provinces of the Commonwealth be split. The western part of this territory, "where Poles are more numerous and where Polish influence decidedly dominates", was to belong to Poland. The Polish representatives, on the other hand, would give up the eastern parts of Belarus, Volhynia, Podole and the Polesie regions. Thus, the eastern boundary of Poland would have stretched from Dyneburg (nowadays Daugavpils) in the north down to Kamieniec Podolski in the south. Woodrow Wilson was in favour of the boundaries presented, but at that time this was of limited political significance.

After the ultimate defeat of the central countries, a new European order was to be established by the peace conference, organised by the victorious powers. On January 18th, 1919, the conference started in Paris by establishing the Highest Council, composed of the representatives of the United States, Great Britain, France, Italy and Japan. Representatives of other allied countries were also invited. Poland had the right to delegate two representatives. A number of territorial commissions were established, including one for Poland, chaired by the French diplomat Jules Cambon (Kumaniecki 1924; Cieślak \& Basiński 1967).

The issue of the Polish eastern boundary was not a subject of deeper interest at the Conference of Versailles. The additional proposals and suggestions which were put forward were not favourable. Initially, the Polish delegation tried to promote the idea of returning to the boundaries as of 1772 , i.e. those from before the partitions of Poland. The delegates did this for tactical reasons, for there was awareness that such demands were unrealistic. The Polish stance was presented on January 29th, 1919, by Roman Dmowski. In this very important sound speech the suggestions for the Polish boundaries were presented. They concerned primarily the delimitation of the Polish western boundary. Likewise, the geopolitical conditions were outlined for Poland and Bolshevik Russia.

The Highest Allied Council delegated the question of the Polish boundaries for further consideration and for the preparation of concrete proposals, to the earlier mentioned Cambon Commission. Polish representatives prepared the appropriate evidence supporting the proposal of the Polish eastern boundary for this Commission. This material was composed of two parts in the form of a memorandum, and was issued on March 3rd, 1919. In the first, introductory part, the characteristics of the territories annexed by Russia were presented. In the second part, the Polish territorial demands were formulated. The suggestion was to incorporate into Poland the border-adjacent ar- eas in the North and East up to the long line, stretching between the Baltic Coast near Libawa and the Carpathian Mts. Based on the March 3rd, 1919 note handwritten personally by Dmowski, one can determine quite precisely the territorial claims concerning the eastern boundary, formulated on behalf of Poland, which thereafter were called the Dmowski line.

From the very beginning this proposal was called the Dmowski line. Later on, the line underwent a modification in the northern part when incorporation of Lithuania became altogether doubtful. Although the concept was forwarded by the Polish representatives during the conference in Versailles, it soon lost validity and was, instead, treated as evidence of grand Polish demands.

Determination of the position regarding the course of the Polish eastern boundary was the subject of discussions within the Sub-commission for Polish Matters. The head of the Sub-commission was General Henri Le Rond. This Sub-commission began its work on March 20th, 1919. Five meetings of this body had taken place by the end of March. On April 7th, 1919, the last meeting took place, during which the results were passed on to the Chair of the Commission for Polish Matters, Jules Cambon. On April 22nd, 1919, the final proposal for the boundary was adopted by the Commission. The report prepared by the Commission said: "The Commission unanimously made the decision to: approve the line, defined in Annex one to this report as the eastern boundary of Poland, stretching between the former boundary between East Prussia and Russia and a point to the east of Chełm" (Wyszczelski 2008: 114).

In principle, the delimitation presented was in agreement with the later "Curzon Line", without, however, taking a stance with regard to the division of the province of Galicia. The demarcation line suggested, therefore, had a temporary character, since the final course of the boundary was supposedly to be determined together with the future government of "white" Russia. This expected future government was the one that would have been the legal successor to the authority from before the Bolshevik revolution, the loyal member of the Entente Cordiale. It would be this hypothetical future Russia that would have had the decisive voice on the matter. This was a disadvantageous decision for Poland. It resulted from the fact that on March 9th, 1919, the Russian Political Council in Paris submitted a note to the Peace Conference demanding that Russia have the entire right to decide on the future of the territories that had belonged to Russia before 1914. Due to pressure from the western allies an exception was made for the ten governorships of the Polish Kingdom (with exclusion of the Suwałki Governorship). Meanwhile, on the 9th and 10th, of April, 1919 the Highest Allied Council received a declaration from the Russian Political Council. This declaration stated that on the territory of eastern Galicia the majority of inhabitants were Russians who demand being included in Russia. The representatives of "white" Russia explicitly treated Ukrainians and Belarusians as a part of the Russian nation. At that time, it was not clear what would be the outcome of the civil war in 
Russia. The Sub-commission of Le Rond was not capable of predicting "whether Poland in Eastern Galicia will border upon the Ukraine or upon Russia, and if upon Russia - then ruled by whom" (Żurawski vel Grajewski 1995: 25).

Determination of the western boundary of Russia was quite a complex issue for the western powers from the point of view of international law. The complexity had an impact on the attitude of these countries with respect to the Polish eastern boundary. Dmowski emphasised this matter in his known book: "An important doubt arose, first of all, about whether the Peace Conference could establish the boundary between Poland and Russia when the latter was absent. Russia was not a defeated country, quite the contrary, it had belonged to the coalition fighting with the central countries (...) Keeping, too strictly to this position, though, would mean the establishment of Poland would be impossible, since the main, central part of Poland, the former Congress Kingdom [Polish Kingdom], was also considered, with the tacit approval of the powers, as belonging to the territory of Russia. Although the temporary government of Russia in 1917 recognised the independence of Poland, it did not delineate the boundary between Poland and Russia (...). The Presidium of the Conference requested that the Polish delegation present their suggestions concerning the eastern boundary. Although we did this [meaning the so-called Dmowski line], no discussions were undertaken on this matter with us. We have understood as well, that this matter shall be decided in the future, depending upon the further fate of Russia, and that it must first of all be decided between us and Russia. Later on only the powers attempted to establish a minimum boundary of Poland in the East, in the form of the so-called Curzon Line" (Dmowski 1947, 2: 47).

The political setting was further complicated by the fact that since the end of 1918, the territory of eastern Galicia was the area of heavy military conflict between reborn Poland and the Western-Ukrainian People's Republic (WUPR). At the turn of 1919, the Polish-Ukrainian line of fighting stabilised along the upper stretch of the San River, but Lviv, together with the railway line Przemyśl-Lviv was in Polish hands. The western powers were interested in an armistice between the two fighting sides, since this could strengthen the anti-Bolshevik forces. For this reason, on February 15th, 1919, a corresponding mediating commission was established, headed by General Joseph Barthélemy. He went to Galicia, but his mediating mission ended with a fiasco. The effect of his endeavour was a proposal for the division of the disputed territory, submitted on February $22 \mathrm{nd}$ in Lviv to the representatives of Poland and WUPR. According to this proposal, Lviv, as well as the Oil Basin of Borysław and Drohobycz, would remain on the Polish side, while Tarnopol and Stanisławów - on the Ukrainian. The boundary would go along the Bug River up to Kamionka Strumiłowa, and then pass $20 \mathrm{~km}$ to the east of Lviv. On the southern stretch, Bóbrka was left on the western side. Meanwhile, the Ukrainians demanded Jarosław, Przemyśl, Sanok and Lesko (nowadays well inside the Polish territory). The design for the armistice and establishment of the de- marcation line according to the concept of Barthélemy was not accepted by the government of WUPR. At the end of February, the Polish side suggested the demarcation line connecting Sokal-Busk-Halicz-KałuszCarpathians. A couple of months later, the line was shifted slightly to the West by Józef Piłsudski, to SokalBusk-Kałusz-Carpathians. Both these variants assumed that Lviv would remain in Poland, and so they were not accepted by the Ukrainian side.

The Highest Allied Council attempted to end the Polish-Ukrainian conflict by establishing the Inter-Allied Mediation Commission, headed by General Louis Botha, on April 2nd, 1919. This Commission organized the so-called peace convention in which the demarcation line was defined. It was not meant to prejudge the future boundary between the two countries. With respect to Barthélemy's previously proposed line, this new line was slightly shifted to the west, since the Drohobycz-Borysław Oil Basin would be left on the Ukrainian side (Fig. 1). The complex issues dealing with the division of Galicia into two parts are presented in a detailed manner in two valuable reports: Batowski (1979) and Mroczka (1998).

The course of events in eastern Galicia was constantly monitored by the Highest Council. For this reason, the Commission for Polish Matters was asked to prepare appropriate territorial proposals. On June 17th, 1919, the Commission presented three variants of a solution that was meant to lead out of the stalemate. The first variant was to establish a mandate over eastern Galicia, residing with the League of Nations or with one of the world powers. The second variant was to incorporate the territory into Poland, with the understanding that there be preserved a definite autonomy. The third variant consisted in the establishment of a temporary administration and organisation of a plebiscite, whose outcome would be binding for both sides of the conflict. In each of these variants, a division was envisaged between eastern and western Galicia. Two dividing lines were proposed, with the ultimate decision being left to the Highest Council. Under line ' $A$ ', the oil basin and the city of Lviv remained on the eastern side. This proposal was similar to the later Curzon Line. Under line 'B', both Lviv and the oil basin would be incorporated into Poland proper (Fig. 2). Opinions differed within the Highest Council. The American, French and Italian members of the Commission opted for line ' $B$ ', while Lloyd George, as the head of the British delegation, was more inclined towards line ' $A$ '.

Ultimately, the Foreign Ministers of the countries represented on the Highest Council made a decision on June 18th and 25th, to grant Poland the right to introduce a temporary administration in the entire area of eastern Galicia. There was a recommendation to conduct a plebiscite and guarantee autonomy in the future.

The mediatory decision of the allies soon lost its validity because in July 1919, Polish troops took all of Galicia up to the Zbrucz river. This gave rise to a clear disapproval in Paris. The British side, including Lloyd George, accused the Polish government of putting into practice the policy of facts using military force, against 


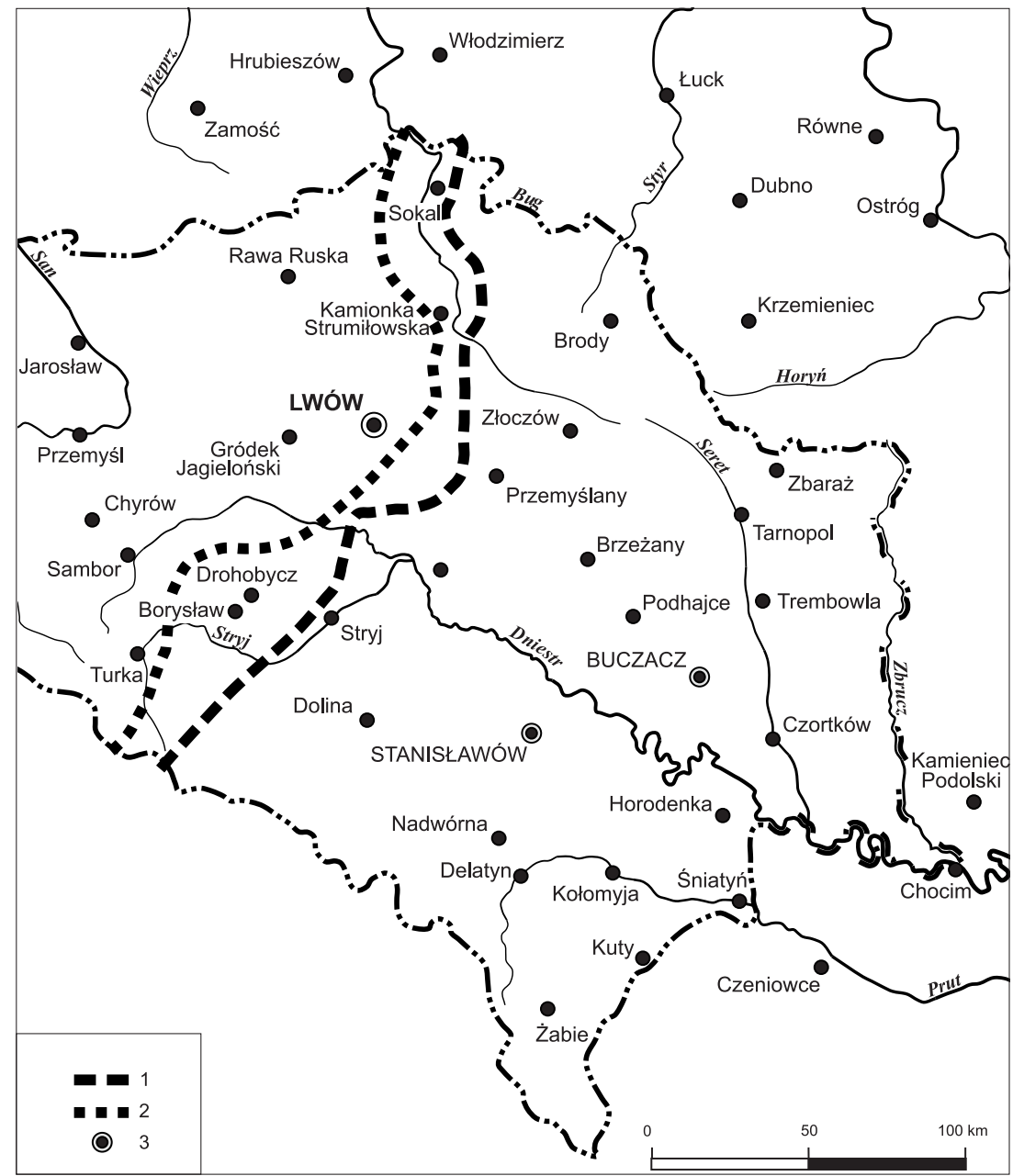

Figure 1. The lines (boundaries) dividing Galicia according to the proposals of General Barthélemy and General Botha. Signatures: 1 - The Commission of General Barthélemy of 15 February 1919; 2 - The Commission of General Botha of 9 May 1919; 3 - The temporary seats of the WUPR government.

Source: on the basis of Żurawski vel Grajewski (1995: 118).

the recommendations of the western allies. Later on, the attitude of the western powers with respect to the Polish eastern boundary started to undergo a certain change. This change in attitude was associated with the role of Poland as the opponent of Bolshevik Russia. Yet, the Cambon Commission still did not envisage inclusion of eastern Galicia into Poland on the principle of unconditional incorporation. Based on the decision of November $21 s t, 1919$, Poland was given a mandate limited to 25 years, with an obligation of granting territorial autonomy. Due to the protest from the Polish government, on December 22nd, 1919, this decision was suspended and there was a return to further negotiations.

The issue of the Polish boundary within the territory of the former Russian Empire was not legally resolved. Up till the very end of the Peace Conference in Versailles; May 7th, 1919, the allies were not capable of making a binding decision. The opinion was that the question must be accepted by the new Russian government, which would be formed after the Bolsheviks were defeated. Thus, in the ultimate peace declaration, this issue was not explicitly addressed. The extra time was advantageous for the Poles, since it allowed for the continued hope of regaining a part of the eastern territories of the Polish-Lithuanian Commonwealth. First, though, Bolshevik Russia needed to be defeated in military terms and forced to undertake serious peace talks.

In 1919, the Polish army gradually moved towards the east. Between March and September, Polish troops took Vilna, Baranowicze, Równe, Minsk and reached the line of the Berezyna River, taking also Borysów and Bobrujsk. On the southern part of the frontline, after the troops crossed the Zbrucz River, Kamieniec Podolski was also taken (Fig. 3). 


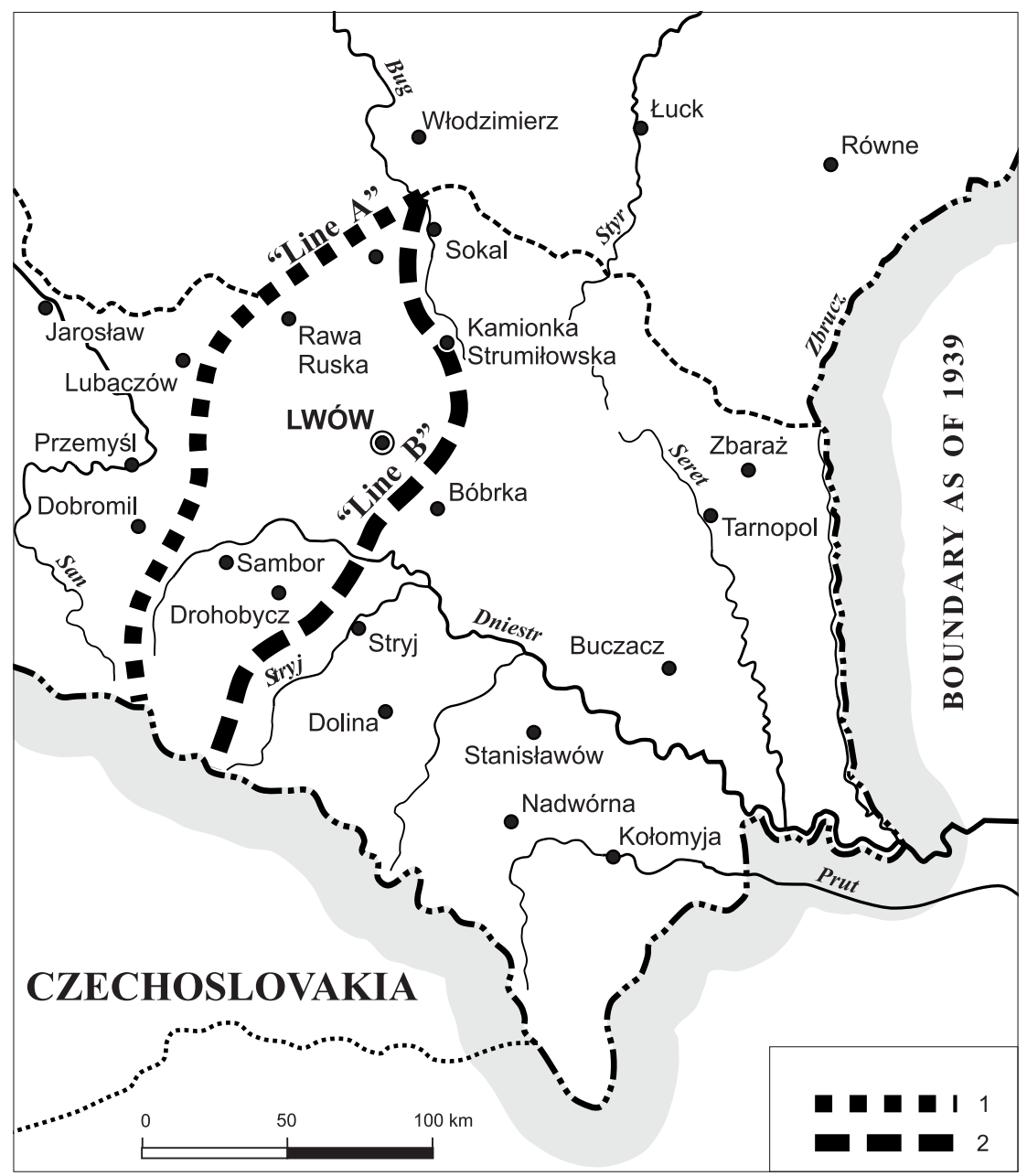

Figure 2. Division of Galicia according to the later Curzon Line (variants ' $A$ ' and ' $B$ '). Signatures: 1 - Curzon Line ' $A$ '; 2 - Curzon Line ' $B$ '.

Source: on the basis of Kirkien (1944: 64).

The military successes of Poland were not acknowledged with satisfaction by the countries of the Entente, but protests were low-keyed and expressed in a vague manner. It was uncertain who would win in the civil war in Russia. Support was extended to the "white" generals and the allies were aware that in case the "whites" won, only the loss of the territory of the Polish Kingdom would have been acceptable for them. On the other hand, Poland was treated as a "sanitary cordon" separating Bolshevik Russia from humiliated, defeated Germany. For this reason, Poland was getting a significant military support from the allies and it was expected the situation would soon be clear.

On December 8th, 1919, the Highest Allied Council defined the demarcation line based on ethnic and historical criteria. The Council founded their decision on the design elaborated by the Commission for Polish Matters. It was similar to the boundary of the Tsarist Empire of 1795, established after the 3rd - final - partition of the Polish-Lithuanian Commonwealth. The de- cision was made by the Highest Council of the peace conference, signed by the President of the Highest Council of the Allied and Associated Countries, Georges Clemenceau, on December 8th, 1919. The line was very precisely determined according to the consecutive topographic points: "Starting from the former Austrian border along river the Bug River, up to the point that the administrative boundary of the counties of Brześć and Bielsk Podlaski cross, then towards the north approximately $9 \mathrm{~km}$ north-east of Mielnik, thereafter to the east, crossing the railway line Brześć Litewski-Bielsk near Kleszczele, then two kilometres to the west of Skupowo, $4 \mathrm{~km}$ to the north of Jałówka, and along the Świsłocz River, diverging to the west of Baranowo through the locality of Kiełbasin by Grodno, then along Łosośna River, the tributary of Niemen up to Studzianka, Marycha over Zełwa, Berżniki, Zegary" (Kumaniecki 1924: 177).

This dividing line started in the north at the mouth of Czarna Hańcza flowing into the Augustów Canal, 


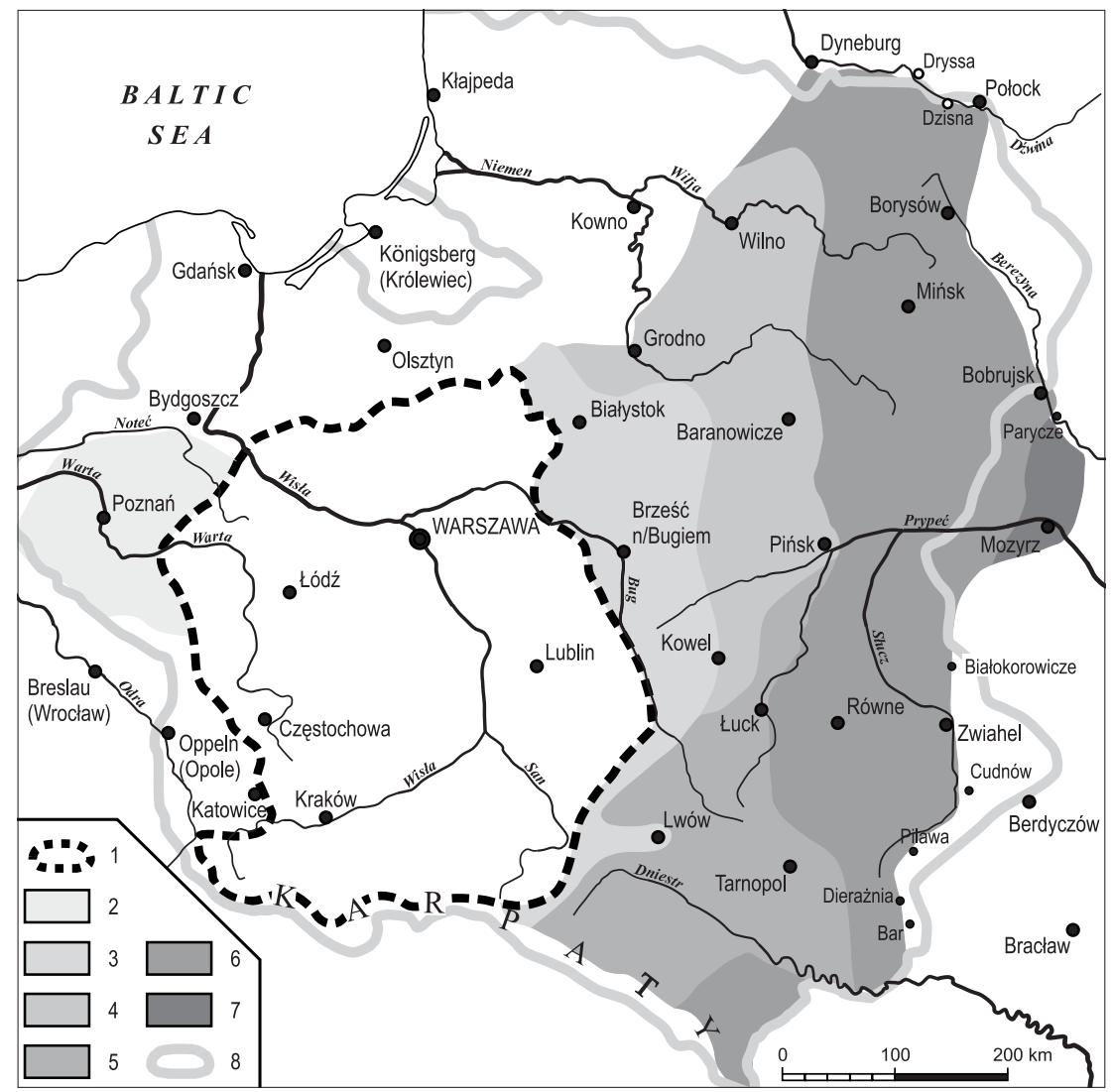

Figure 3. The effects of the military operations of the Polish army. Areas taken in the period between the end of 1918 and the beginning of 1920. Signatures: 1 - November 1918; 2 - January 1919; 3 - February 1919; 4 - May 1919; 5 - July 1919; 6 - August-December 1919; 7 - March 1920; 8 - Dmowski line.

Source: on the basis of Gasiorowska-Grabowska \& Chrienow (1961).

and along this canal to the Niemen River. Then it went along this river directly by Grodno, leaving on the Polish side the railway station of Łosośne. Further on it moved away from the river. Near Jałówka, it took a southward course, reaching the Bug River in the area of Niemirów. Krynki was left on the western side. On the eastern side, Białowieża was included together with almost all of the Białowieża Forest, as well as Wysokie Litewskie and Wołczyn. Then the line followed the course of the Bug River, with the town of Brześć on the eastern side. Following the course of the Bug River the line was to reach the area of Hrubieszów and Sokal, and there it ended. This line did not go on to divide Galicia, situated more to the south. The course of the adopted line conformed to the boundary which later on gained the ill-famed name of the "Curzon Line".

The demarcation line of December 8th, 1919 did not have a final character. At that time, as well, it was stated that Poland was given the rights to the territories situated to the east of this division. The determination of this line only meant that Poland was entitled to organise a permanent administration in the areas to the west of this dividing line, while Polish claims to the areas situated more the east were fully justified and meant to be respected. Hence, the respective decisions were not altogether binding. It was only the later exaggerated interpretations that were used to show the decision as final as far as the establishment of the boundary between Poland and Bolshevik Russia was concerned. In any case, the decisions taken on December 8th, 1919, brought very serious consequences. These decisions were referred to many times later on, with suggestions that they conformed to standards of international law and should be regarded as a firm legal reference.

Yet, in the then current political and military situation these decisions were of secondary significance, since the Polish-Bolshevik line of fighting was situated $300 \mathrm{~km}$ to the east of the considered line. On December 23rd, 1919, fearing defeat in the war with Poland and because of internal problems, the Bolshevik government made a peace agreement offer. On January 28th, 1920, this offer was renewed through a declaration, signed by Lenin, Chicherin and Trotsky. The suggested cease-fire line would be geographically similar to the Dmowski line. The offer differed from the Polish proposal only in details. Thus, while this offer would not grant Poland the city of Połock and the areas situ- 
ated to the north of the Dvina River, it would cede to Poland the area in the vicinity of Bar in the Ukraine. It was implied, that the cease-fire line could become the boundary between the two countries. It may be supposed that this attractive proposal had a tactical character. After the demobilisation of the Polish army, it seemed that any pretext could be used to question it in the context of the necessity of promoting the heralded world revolution, or of assisting the Polish or German proletariat. After a long delay, on April 6th, 1920, the Soviet memorandum was finally rejected by the Polish side (Gqusiorowska-Grabowska \& Chrienow 1961, 1964).

Defeats followed the Polish army's military successes. After the Polish army lost Kiev to the Bolsheviks, complete defeat followed in the Ukraine and Belarus. The Red Army started its victorious march westwards. The potential downfall of Poland was at stake when the governments of Entente undertook a peace initiative. The aim was a cease-fire and peace agreement.

The international allied conference in Spa took place on July 10th, 1920. During the meetings, the British put forward a proposal for the withdrawal of the Polish troops towards the demarcation line defined by the meridional course of two rivers: Niemen and Bug. The territorial decision concerning eastern Galicia would be left to the competence of the powers of Entente. The demarcation line in Galicia would be defined according to the position of the Polish-Bolshevik line of fighting. At that time, the war front had only approached the Zbrucz River from the east. The area of the Oil Basin and the city of Lviv were still not directly threatened. It was assumed that Galicia would be divided up by the demarcation line, running to the east of Lviv. The respective design was forwarded by Lloyd George, who clearly referred to the allies' statement of December 8th, 1919. His intention was to determine a demarcation line that would satisfy both sides of the conflict, which would have guaranteed an end to war. A decision was made to immediately send the proposal of the western powers to the Commissar for Foreign Affairs of Bolshevik Russia, Georgiy Chicherin.

Right after the decision had been taken, a cable was sent out in the night of the 10th to the 11th of July, 1920, from the Foreign Office of Great Britain. The cable was signed by the Foreign Secretary, Lord Curzon, addressed to the Commissariat for Foreign Affairs, to be personally delivered to the hands of Chicherin. According to the most reliable account, this official duty was carried out by Lewis Bernstein-Niemirowski (who used the name Namier). He was an influential person, closely associated both with Lloyd George and with Lord Curzon. He had his own opinion about the situation in Galicia and was supportive of the Ukrainian side. The content of the cable message was changed. The proposal for the course of the demarcation line in Galicia was shifted in such a way that Lviv and the Oil Basin were left on the eastern side of the divide and this was what reached the Commissar for Foreign Affairs of Bolshevik Russia (Chicherin). The motivations for the behaviour of Namier are fully explained. The change was, in fact, quite in line with the views of Lloyd George and Lord Curzon. That is why it can be sup- posed that the change was not an accidental or technical error, but an intended modification. The British side did not attempt to clarify this change and did not treat it in a very serious manner.

Hence, the Bolshevik government obtained a concrete proposal for a cease-fire demarcation line. It was precisely defined and ran from the Augustów Canal in the north to the Carpathian Mts. in the south.

The Bolsheviks rejected the Entente's demarcation line proposal. This was done formally on July 17 th, 1920. The Bolshevik government, including Lenin, counted on a fast victory over Poland and on reaching the German border. The Bolsheviks assumed the world revolution would soon occur which would entirely change the European order. That is why the intermediation of the Entente countries was considered superfluous. In order to hide their actual objectives, the Bolshevik diplomacy announced the need of direct Polish-Bolshevik negotiations. In practice, though, the aim was to enslave Poland and turn it into another Soviet republic. The conference in Spa was held on July 10th, 1920. At the conference, the Polish delegation agreed to conclude the cease-fire and to withdraw the armed forces to the demarcation line, proposed by Lloyd George, that is - to the Curzon Line. Yet, given that the Bolshevik side did not agree to this, the Polish consent had no political nor military significance.

The following conference of the allies took place in August 1920 in Sèvres. At this time, the Red Army had already reached the line of the Vistula River and the fate of Poland seemed to be doomed. The western powers undertook an attempt to save the separate character of eastern Galicia by promising to establish eastern Galicia as a sovereign political entity. This was fully ignored not only by Bolshevik Russia but also by Poland.

The Polish victory in the Battle of Warsaw, and then the defeat of the Red Army over the Niemen River and close to Komarów in the region of Lublin, again entirely changed the military and political situation. When the Polish army reached Minsk and crossed the Zbrucz River, the Bolshevik side became aware that defeating Poland might be beyond its real capacities. Peace negotiations were started, and ended by the establishment of the new eastern boundary of Poland at the conference in Riga on March 18th, 1921. The respective decision was ratified by the Polish Diet on April 15th, 1921.

This Polish-Soviet border with a length of $1412 \mathrm{~km}$ stretched from the Dvina River in the north, that is - from the Polish-Latvian border, eastwards to the Drissa River and then southwards to the vicinity of Raków, Stołpce and Dawidgródek. There it crossed the Prypeć River and reached the Zbrucz River. It touched the Polish-Romanian border where the Zbrucz and Dnester verged. Hence, all of Galicia (having belonged before to the Austrian partition), major parts of the regions of Volhynia and Polesie, the region of Vilna and the western part of the region of Minsk were incorporated into Poland. The new boundary was very close to that of the second partition of Poland (1792).

The boundary established at the Treaty of Riga had not been questioned by the Soviet authorities during 
the entire inter-war period. The Curzon Line, discussed in the years 1919-1920, was virtually forgotten. It was not being brought back and was treated as an outdated episode of the peace negotiations.

\section{Establishment of the Curzon Line as the eastern boundary of Poland during the World War II}

The Red Army crossed the Polish-Soviet border on September 17th, 1939. Aggression against Poland had been preceded by the August 23rd, 1939 treaty between the German Reich and the USRR. On the basis of this agreement the territory of Poland was divided between the two neighbouring powers. The dividing line was along four rivers: San, Vistula, Narew and Pisa. This line was then changed in a subsequent agreement signed by the two invaders on September 28th, 1939. The new demarcation line shifted from the line of the Vistula to the line in the middle of the Bug River (see also: Eberhardt 1993). So, the region of Lublin, in exchange for Lithuania, was incorporated into the German occupation zone. The boundary between the two zones started in the south at the upper course of the San River. Then, going along the course of this river, it reached Sieniawa which was in the vicinity of Jarosław. There, the dividing line deviated from the San and went along a straight course to Krystynopol, situated on the western side of the Bug River. Starting from that point, it went over a long segment along the Bug River up to Nur. At this point, the line diverged from the river and ran a straight course till it reached the Narew River in the vicinity of Ostrołęka. Further on, the dividing line followed the course of the Narew River, reached the Pisa River and then reached the boundary of East Prussia. Due to the efforts of Ribbentrop, the USSR ceded to Germany the region of Suwatki. After the German-Soviet "boundaries of friendship" treaty had been signed, both sides considered the adopted line as the ultimate one. Later on, it was referred to as the "Ribbentrop-Molotov demarcation line". This line effectively lasted from September 28th, 1939 to June 22nd, 1941.

The line thus defined did not conform to the socalled Curzon Line. In a later period, the Soviets tried to identify it with the Curzon Line, but this was not true. Only over the middle segment, along the Bug River, did the two lines coincide. In the south, the demarcation line was determined along the upper course of the San and was shifted to the west in relation to the Curzon Line in the area of Bircza and Lubaczów. The two lines differed significantly over the northern segment, since the province of Biatystok (except for the counties of Grodno and Wołkowysk) were on the western side of the Curzon Line. In the German-Soviet division - both the one of August 23rd, 1939 and the one of September 28th, 1939 - the entire province of Białystok, along with three counties of the province of Warsaw, were incorporated into the Belarusian SSR.

The German-Soviet war started on June 22nd, 1941. The demarcation line established on Septem- ber 28th, 1939, was crossed by the German troops along its entire length and actually ceased to exist. The Soviet-German treaties lost significance and the problem of the future of Poland, as well as of her eastern boundaries, became again an open question. The entire territory of pre-war Poland was occupied by Nazi Germany. The Soviet-German boundary disappeared, and the German administration introduced new administrative divisions. Eastern Galicia (Eastern Małopolska) was incorporated into the so-called General Governorship as a separate district. The entire region of Volhynia and southern Polesie were included in the so-called Reichskommissariat Ukraine. The province of Białystok was incorporated into East Prussia. The land of north-eastern Poland was included in the so-called Reichskommissariat Ostland.

Hitler's aggression against the USSR was an advantageous occurrence for Great Britain, since this meant gaining a strong ally. The treaty on the common activities of the governments of the USSR and Great Britain against the Germans was signed on July 12th, 1941, in Moscow, by Molotov and Cripps in the presence of Stalin. At the same time, talks had started between General Władysław Sikorski, who was the Prime Minister of the Polish Government in Exile in London and Ivan Maisky, who was the Soviet ambassador in London. These talks revealed serious differences of opinions concerning the course of the Polish-Soviet boundary. The Polish side demanded that the PolishSoviet boundary established in the Treaty of Riga be respected. Maisky maintained that the boundaries cannot be based on this Treaty. He stated that new boundaries must be established on the basis of ethnographic criteria, since the Soviet government would not accept the boundaries of 1939 .

In view of these difficulties, Churchill and Foreign Secretary Anthony Eden, personally entered the negotiations. Due to strong pressure exerted on the Polish government, a new Polish-Soviet agreement was finally signed on July 30th, 1941, by Sikorski and Maisky. The two governments renewed diplomatic relations. The issue of returning to the pre-war boundaries was formulated allowing for a highly arbitrary interpretation. The respective formulation was simply: "The government of the USSR admits that the Soviet-German treaties of 1939, concerning the territorial changes in Poland, are no longer valid". The issue of the boundaries was commented upon differently by the two sides and was left hanging for later negotiations. The Polish government maintained that invalidation of the treaties with Germany meant the return to the boundaries established in Riga. Yet, for the USSR, annulment of the treaties with Germany did not have to entail the re-establishment of the pre-war boundaries. This lack of precision in the formulation of the agreement caused great calamity in the Polish government in London. No significant political consequences, however, resulted. On the other hand, the Soviet governmental daily, Izvestiya (August 3rd, 1941), noted that the issue of the Polish eastern boundaries remained open, that the Treaty of Riga was not valid forever, and that the territories of eastern Poland are really Ukrainian and Belarusian lands, and not Polish (Pobóg-Malinowski 1981). 
The issue of the Polish-Soviet boundary was taken up during Sikorski's visit to Moscow in December 1941. During the talks with Sikorski, Stalin suggested considering the issue in bilateral negotiations. Sikorski, though, was of the opinion that the boundary established in Riga could not be questioned and did not follow this suggestion. During the second half of 1941, there were a series of defeats of the Red Army. At this time, Moscow did not put forward any concrete proposals concerning the boundary. The historical proposal of Lord Curzon, dating from 1919, was also not recalled. After the victory over the German troops at Moscow, the attitude of the Soviet side became increasingly unyielding. In response to the memorandum from the Polish government, the Soviet government stated that "incorporation of the indicated areas (that is - western Ukraine and Belarus) into the USSR was the result of the freely expressed will of the population" (Pobóg-Malinowski 1981: 220).

At this time, the British side started to acknowledge the Soviet arguments. This was revealed in the talk between Sikorski and Cripps on January 26th, 1942. The British ambassador in Moscow stated that "What concerns the Polish-Russian border, Russia shall forward rather far-reaching demands. In the unofficial Russian circles the Curzon Line is even being mentioned" (Karski 1998: 343-344). This was the first time that a representative of Great Britain recalled the Curzon Line as the potential eastern boundary of Poland. The position of Great Britain with respect to the Soviet territorial postulates had started to undergo an essential reorientation (Karski 1998). This transformation resulted from Churchill's apprehensions over the possibility that a separatist peace could take place between Germany and the USSR. This was completely unrealistic, but entailed the politics of ceding to the Soviet demands.

During 1942, the Soviet side signalled many times over that the boundaries of June 1941 (that is - the ones established as a consequence of the RibbentropMolotov pact) are considered by them to be legally binding. The boundaries set up by this pact were not, of course, binding on the basis of that agreement, but on the basis of the plebiscite, organised among the population of western Belarus and Ukraine. At the end of 1942, the Polish government again brought up the issue of the Polish-Soviet boundary. The Soviet position was increasingly unyielding and opposed to change. The Polish claims played a less significant role in the eyes of the western allies. The Soviet responses moved farther and farther away from a compromise, the Soviets remembering the necessity of returning to the June 1941 boundary. The Soviets started to proclaim the need to determine the boundary on the basis of the historical proposal of Lord Curzon. This can be seen in the note of the Soviet agency TASS of March 1st, 1943, regarding the motion of the Polish government made on February 25th, 1943. This note stated that: "The Soviet leadership is of the opinion that negating the right of the Ukrainian and Belarusian nations to unite themselves with their brothers constitutes evidence of imperialist tendencies, and the reference made by the Polish government to the Atlantic Charter has no foundations.
The Atlantic Charter does not give anybody the right to take away the national rights of the Ukrainians and Belarusians, but to the contrary - it assumes the national right of the peoples, including the Ukrainian people. Even the known British minister, Lord Curzon, despite his persistently negative attitude towards the USSR, understood that Poland cannot pretend to incorporate the Ukrainian and Belarusian lands. Yet, even now, the Polish ruling circles do not wish to show an understanding of this matter" (Stanisławska 1965: 338). The Polish response to this note stated that the Curzon Line was merely designed as a cease-fire demarcation line and not as a boundary, during the military operations of the years 1919-1920. This kind of dispute had very limited significance. It was similar regarding the Polish intervention with the western allies. For Great Britain and the United States, this was a secondary issue. Relations with the USSR were important and there was no desire for unnecessary discussion over this question. On the other hand, the Soviet arguments were more understandable for Great Britain and the United States. They thought the USSR, having borne such great sacrifices in the war, had the right to determine a western boundary which conformed to its military needs.

Diplomatic relations between the Polish government and the USSR grew increasingly tense. They were finally severed under the official pretence related to the Katyń crime and the fact that the Polish government turned to the International Red Cross. The growing political isolation of Poland lowered the chances of exerting effective influence. Being aware of these unfavourable circumstances, Sikorski started to think of potential territorial concessions. He thought of giving up Polesie, Volhynia and a part of Podole - in exchange for territorial compensations at the expense of Germany. He intended to travel to Moscow for direct talks with Stalin. Before the planned visit, though, he died tragically in a plane crash on July 4th, 1943. Stanisław Mikołajczyk became the new Prime Minister of the Polish government. In the course of preparations for the Moscow conference of the foreign ministers from the three main powers, the British side tried to impose on the government of Mikołajczyk the necessity of recognising the Curzon Line as the Polish-Soviet boundary. This suggestion was rejected, and the Polish government still opted for the maintenance of the boundary from the Treaty of Riga.

The future of Poland and her political boundaries were to be determined at this meeting of the leaders of the three superpowers, that is - Stalin, Roosevelt and Churchill. It took place on November 28th - December 1st, 1943, in Teheran. The meeting was decisive for the course of the Polish eastern boundary. The respective negotiations ought to be presented in as accurate a manner as possible (see also: Daszkiewicz \& Rotfeld 1970). Initially, Stalin's position was unyielding. The sole just solution for the USSR was the demarcation line which existed between 1939 and 1941. The declaration of Stalin's position was complemented by Molotov, who maintained that the boundary of which Stalin spoke, was the Curzon Line. The British participants at the meeting questioned the opinion 
expressed by Molotov. They laid a map out on the table which marked the differences between the Curzon Line and the dividing line of June 22nd, 1941. The Curzon Line left the majority of the Białystok province on the Polish side. After awhile, Molotov saw that his attempt to mislead the western allies had failed, and Stalin ultimately admitted that the two lines did not coincide.

In the further course of the discussion, the subject of the southern segment of the Curzon Line was considered. Eden reminded the others that in this part of the territory, that is - in Galicia - the Curzon Line was not determined, and that Lviv ought to remain on the Polish side. In response to this statement Molotov sent the secretary to get the Soviet maps, and then read out the entire text of the note sent to the government of Bolshevik Russia by Lord Curzon on July 11th, 1919. This document was the one which had established the cease-fire division. It did not clearly indicate which of the two variants previously mentioned, ' $A$ ' or ' $B$ ', should be implemented. This entailed a debate over interpretation. Eden defended the Polish interests, indicating that Lviv ought to belong to Poland. At this instant, Churchill turned to Eden and said that he would not have his heart broken over Lviv. Then, in the presence of Molotov, he repeated the expression that has become known as: "I do not intend to weep over Lviv".

At the end of the meeting, Churchill spoke and proposed the initial version of the final resolution containing the following content: "It was agreed in principle that the focus of the Polish state and nation ought to be located between the so-called Curzon Line and the line of Odra river, with inclusion into Poland of East Prussia and the province of Opole". Stalin responded to this proposal of Churchill's by demanding the northern part of East Prussia, including Królewiec (Königsberg, nowadays - Kaliningrad). If this request was fulfilled by the allies, then the Soviet side would agree to the proposal. This demand was accepted by Churchill and Roosevelt. The agreement, reached at the conference in Teheran had an essential significance for the Polish eastern boundary. It was fully determined through the agreement between the three superpowers. Finally, the Curzon Line was established as the eastern boundary of Poland. At the same time, consent was given for the annexation of the northern part of East Prussia by the USSR. Poland not only lost its eastern part, but was also to border the Soviet Union in the north. Thus, regarding the Polish-Soviet border, the demands of the Soviet side were satisfied. The sole concession consisted in giving up the literal return to the demarcation line of 1941. The Curzon Line was mentioned as a general notion, without the concrete consideration of the fate of Lviv. Lviv could be situated either on the eastern or on the western side of the border. Stalin certainly assumed that Lviv would belong to the Soviet Union. Yet, this situation seemed to leave the opportunity for a future reconsideration of the course of the southern segment of the Curzon Line.

The decisions made in Teheran were not officially revealed and were not transmitted by official channels to the Polish government. Immediately after the con- ference in Teheran, the government of Prime Minister Mikołajczyk was unaware that the course of the Polish eastern border had already had been decided upon and that the position of the three powers on this subject was unanimous. For several months after the conference in Teheran, constant talks took place between the Polish government, represented by Mikołajczyk, and Churchill who tried to talk Poles into acceptance of the Curzon Line as the eastern boundary of Poland. This was the precondition for the Polish-Soviet agreement. The Poles did not cede to Churchill's pressure. The sole concession from the side of the Polish government was the proposal of February 16th, 1944, that is - after the Soviet army crossed the pre-war eastern boundary of Poland. Polish government proposed to establish a demarcation line that would run between the boundary from the Treaty of Riga and the demarcation line of 1939, leaving Lviv and Vilna under Polish administration. Likewise, there was opposition against Królewiec being included in the USSR - though it had already been promised to Stalin at the conference in Teheran. This was not a subject of big interest for the three superpowers whose position on the issue was, in principle, agreed upon at that time.

The Soviet way of thinking was brought into the open once again in January 1944, when the Soviet agency TASS officially communicated that "the eastern boundaries of Poland may be established on the basis of an agreement with the Soviet Union. Soviet authorities do not consider the boundaries of 1939 to be unchangeable. These boundaries can be corrected to the advantage of Poland, in the sense that the areas where a Polish population dominates, would be given over to Poland. In such a case the Soviet-Polish boundary could go more or less along the so-called Curzon Line, which was adopted in 1919 by the Highest Council of the Allied Powers, and which envisages the incorporation of Western Ukraine and Western Belarus to the Soviet Union" (Eberhardt 1993: 127). Following this statement by the TASS agency on January 12th, 1944, an article appeared in Izvestiya, showing a map, depicting the differences between the demarcation line of 1939 and the Curzon Line (see Fig. 4).

Having full support of the western powers on the issue of its western boundaries, the Soviet Union started to undertake actions aimed at establishing in Poland an administration that would accept the border agreement between the two countries. From occupied Poland, the delegation of the so-called National Home Council was summoned to Moscow. Together with the so-called Union of Polish Patriots, formed entirely in the USSR, the two delegations were supposed to sign an agreement on the future political boundary between Poland and the Soviet Union. Talks on this subject took place between 22nd and 27th of July, 1944. From the Polish side, E. Osóbka-Morawski, B. Drobner and M. Rola-Żymierski participated. From the Soviet side, Stalin, Molotov and Vyshynskiy primarily participated. The Polish delegates accepted the Curzon Line, in which Lviv would be in the USSR, as the eastern boundary of Poland. Due to the motion from OsóbkaMorawski, the Soviet side agreed to cede a part of the Białowieża Forest as well as Białowieża, to Poland. 
In the memoirs of E. Osóbka-Morawski, this episode was reported in the following manner: "I left the question of the Białowieża Forest for the very end of the discussion with Stalin. According to the design of Molotov, the Forest was to belong in its entirety to the Soviet Union. I referred to the fact that this was a Polish National Park and the area where Polish guerrillas fought many times over for the independence of the country. Besides, I emphasised that Poland's forests were significantly devastated by the occupant, while the Białowieża Forest constitutes the sole resource for the wood processing industry in Hajnówka. Finally, the ethnic problem, which was the main reason for the change of the Polish eastern boundary, did not exist there." These arguments were not quite satisfying for Stalin, but among the Polish delegates OsóbkaMorawski threatened to resign from the position of the head of the so-called Polish Committee for National Liberation. This exerted an influence on the decision of the Soviet side, since Osóbka-Morawski goes on to state: "After about half an hour Molotov phoned me and declared that Stalin consented to incorporate half of the Białowieża Forest, including Białowieża, to Poland. The issue of the boundary was settled" (Osóbka-Morawski 1992: 122-123).

Great Britain and the United States had agreed to the Polish-Soviet border following the Curzon Line, at the conference in Teheran. The Polish puppet organisms that were to take over the authority in Poland, according to Stalin's plans also agreed to the PolishSoviet border, following the Curzon Line. Yet, the entire issue was not completely put to rest. The Polish government in London still enjoyed recognition from the western powers, and it did not agree to the border plan. This was the reason for Churchill's intervention as he tried to force the Polish government to accept the Curzon Line. He was afraid of a marginalisation of the Polish government in London, and that the administration in Poland would be taken over by persons at Stalin's disposal. This was all due to Churchill's persistent illusions. Owing to pressure from Churchill, Mikołajczyk travelled twice to Moscow (on August 3rd, 1944, and October 18th, 1944). The second meeting was also personally attended by Churchill, who went to Moscow in order to mediate between Mikołajczyk and Stalin. The negotiations ended with complete failure since the Soviet side was not willing to make any political concessions or compromises related to the course of the boundary. During the talks, Stalin made a vague offer by saying: "Perhaps it could be possible to make some changes with regard to the Curzon Line that would be advantageous for Poland. Before this can happen, though, you must achieve a mutual understanding with the Poles from Lublin". The position of Mikołajczyk was very difficult, since he was facing Stalin, Churchill and the representatives of the Polish Committee for National Liberation. Being aware of the critical situation and lack of support, Mikołajczyk ultimately consented to significant territorial losses in order to save Lviv. Under pressure, Mikołajczyk adopted the Curzon Line as the starting point for negotiations. Yet, conforming to the decisions of 1919, he agreed to the course of the boundary along the Curzon Line on the northern and middle segments, i.e. in the area of Grodno, Białowieża Forest, and along the Bug River, down to Sokal. The southern segment crossed the territory of former Galicia. Mikołajczyk expressed a readiness to accept variant ' $B$ ', situated to the East of Lviv. Alternatively, while adopting variant ' $\mathrm{B}$ ' as the proper boundary, the temporary demarcation line could be adopted that would go according to variant ' $A$ ', in the immediate vicinity of Przemyśl. These proposals were altogether disregarded. Full agreement without compromise was demanded of Mikołajczyk. He did not consent to this, and so the visit of Mikołajczyk in Moscow in October 1944 ended with failure. The Polish government in London, deprived of support from any of the superpowers, was in complete political isolation. In his speech to the House of Commons of December 15th, 1944, Churchill clearly opted for the variant of the boundary less advantageous for Poland, that is - for the Curzon Line ' $A$ ', giving Lviv and the Oil Basin to the USSR (Stanisławska 1965: 648-649).

The second meeting of the heads of the three superpowers took place on February 4th-11th, 1945, in Yalta in Crimea. There is no need to comment on the discussions which had been going on in the Livadia Palace, since this subject has been taken up many times in the literature. It is known that Stalin and Churchill shared the opinion that the eastern boundary of Poland ought to follow the variant ' $A$ ' of the Curzon Line, which was less advantageous for Poland. The stance of Roosevelt's was less firm. He asked Stalin to reconsider the southern segment of the Curzon Line. Roosevelt also added that this question was not important and that he would leave the decision to the Soviet side. Given this facultative way of putting things in the debate, the position of Stalin was not seriously undermined and ultimately the Soviet variant of the Curzon Line was approved.

The final communiqué, issued on February 11th, 1945 , contained the jointly approved position of the three superpowers. The respective formulation went on as follows: "The heads of the three governments consider that the eastern boundary of Poland ought to go along the Curzon Line, deviating from it in some areas by five to eight kilometres to the advantage of Poland". Although this final document did not specify the precise course of the Curzon Line referred to, there was no doubt that the boundary would go according to the least advantageous variant for Poland, i.e. along line ' $A$ ', leaving Lviv on the side of the Soviet Union. The irreversibility of this decision was further confirmed by the fact that - unlike the western boundary of Poland - it was not meant to be the subject of decisions at the future peace conference.

The subsequent, third conference of the leaders of the Soviet Union, the United States and Great Britain took place in Potsdam and lasted for three weeks (July 17 th - August 2nd, 1945). It was supposed to ultimately decide the course of the Polish western boundary. This boundary had been considered in Yalta in a very general manner, and the final decisions had not been made. During the conference in Potsdam, the course of the Polish eastern boundary was not doubted at all. The decisions made in Yalta were not questioned 


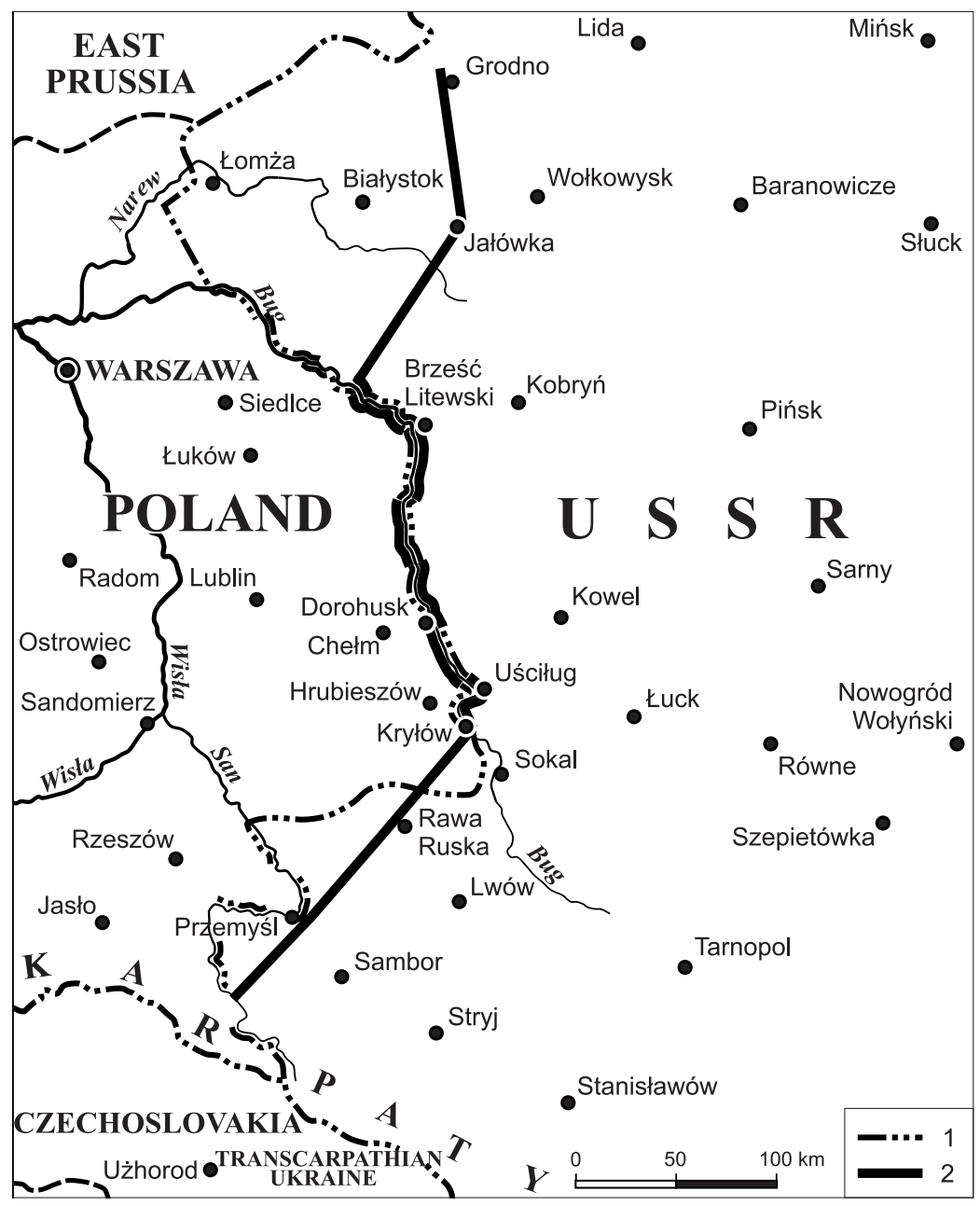

Figure 4. The Curzon Line according to the Soviet view. State boundary: 1 - of the USSR; 2 - the Curzon Line. Source: based on the Izvestiya daily of January 9th, 1944, Moscow.

and the representatives of the three superpowers accepted them fully. The loss of eastern territories to the USSR supported the most important arguments justifying a gain by Poland of some western parts, as if in compensation.

The Polish-Soviet boundary decisions made in Yalta required that a delimitation procedure be carried out. The previous agreement, signed on July 26th, 1944, between the Soviet government and the delegation of the Polish Committee for National Liberation, was not binding and was not completely legally valid from the point of view of international law. In the first half of August 1945, a governmental delegation went to Moscow, which included Bolesław Bierut, Edward Osóbka-Morawski,Stanisław Mikołajczyk, HilaryMincandanumber of skilled specialists, including Polish geographer Stanisław Leszczycki ${ }^{2}$ and Andrzej Bolewski. The team

\footnotetext{
${ }^{2}$ A future founder and director of the Institute of Geography of Polish Academy of Sciences, also the first editor-in-chief of the Geographia Polonica (1964-1981).
}

of specialists prepared concrete proposals for the course of the boundary. Variants were drawn up ranging from the more extreme ones to those more modest, aiming at definite corrections of the established boundary. The Soviet side took an uncompromising stance. The Polish side tried to minimise losses and to achieve some modifications in the course of the boundary to the advantage of Poland (Leszczycki 1992).

Regarding the north-eastern segment of the boundary between the Augustów canal and Jałówka, the Polish negotiators demanded that the boundary conform to the Curzon Line, which reached the Niemen River to the north of Grodno, and along the river course reached Łosośna. This proposal was rejected. The two sides interpreted the Curzon Line differently. The Soviet had biased arguments and no changes could be achieved. The Soviet side was especially interested in the fortifications, situated on the western side of the Niemen River, defending Grodno. On the other hand, a shift of the boundary eastwards 
in the area of the Białowieża Forest was approved. The hottest debate concerned the course of the southern segment of the boundary between Kryłów and the Carpathian Mts. The so-called Bug River Bend was ceded to Poland, because this area belonged to the General Governorship in the years 1939-1941. A long discussion focused on the question of the railway station of Chyrów. This station was used as the link between two important Polish parallel railway lines. All of the Polish arguments on this subject were rejected. It was possible to regain a couple of localities in the vicinity of Przemyśl (including Medyka, situated at the border) and owing to the involvement of the S. Leszczycki, a small fragment of the Bieszczady Mts., situated to the east of Ustrzyki Górne - with Tarnica and Halicz. The majority of the Polish proposals were brutally rejected. Soviet negotiators did not respect one of the stipulations of the Yalta agreement, namely

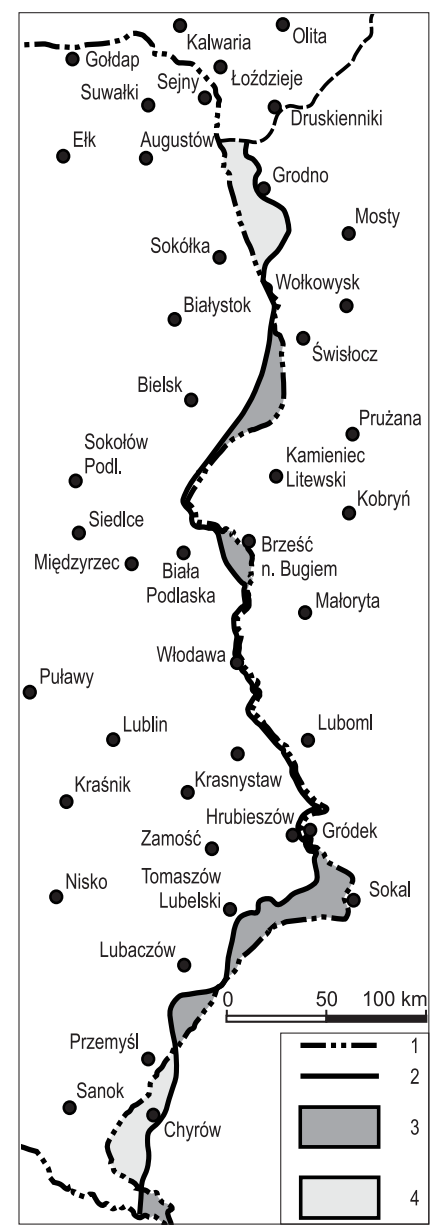

Figure 5. Post-war eastern boundary of Poland and the Curzon Line. Signatures: 1 - eastern boundary of Poland after World War Il; 2 - the Curzon Line; 3 - areas situated to the east of the Curzon Line that were incorporated into Poland; 4 - areas situated to the west of the Curzon Line that were not incorporated into Poland.

Source: on the basis of Demart (2009: 112). the possibility of shifting the boundary away from the Curzon Line by 5 to $8 \mathrm{~km}$ to the advantage of Poland. They were careful to secure the straight line course between the locations specified in the Curzon's 1919 cable. These were the sole directives that the Soviets kept to during the ultimate determination of the boundary (Fig. 5).

The final stage of the conference was the signing of the agreement on the state boundary between Poland and the USSR. On August 16th, 1945, Osóbka-Morawski and Molotov signed the agreement. This agreement contained only very minor deviations from the historical Curzon Line. It was noted in the text of the agreement that the USSR additionally ceded to Poland:

- the area situated to the east of the Curzon Line up to the Bug and Sołokija Rivers, to the south of the town of Kryłów, with the deviation to the advantage of Poland not exceeding $30 \mathrm{~km}$ (this particular area remained within the boundaries of Poland until February 15th, 1951. On that date an exchange took place between the USSR and Poland. The surface area of the territories exchanged was $480 \mathrm{~km}^{2}$. Poland lost the area in question and gained a fragment of territory of identical surface magnitude in the vicinity of Ustrzyki Dolne);

- a part of the area of the Białowieża Forest above the Niemirów-Jałówka segment, situated to the east of the Curzon Line, including Niemirów, Hajnówka, Białowieża and Jałówka, with the deviation to the advantage of Poland not exceeding $17 \mathrm{~km}$.

In the subsequent part of the document, the boundary was precisely described according to the topographic reference points. The boundary between Poland and the USSR across the territory of former East Prussia was depicted as a straight line, though with a distinct curvature in the middle part, owing to which Gierdawy and Pruska lławka were left on the northern, Soviet side of the border.

\section{Final remarks}

The establishment of the eastern boundary conforming to the Curzon Line brought the loss of $179,000 \mathrm{~km}^{2}$ of Polish territory. This was equivalent to $46.1 \%$ of the pre-war territory of Poland (Fig. 6). This happened despite the fact that Poland fought on the side of the allies from the very first until the very last day of the war, and was a member of the victorious coalition. On the other hand, Poland gained an important western territorial compensation; a total area of $102,800 \mathrm{~km}^{2}$, meaning the net loss amounted to $76,200 \mathrm{~km}^{2}$, or roughly $20 \%$ of the pre-war territory.

The signed boundary agreement, though, made void in a definitive manner the partitioning treaty between Ribbentrop and Molotov. In relation to the demarcation line associated with that treaty, which existed between September 28th, 1939, and June 22nd, 1941, distinct changes took place to the advantage of Poland, amounting altogether to $22,000 \mathrm{~km}^{2}$. 
The events of World War II leading to the eventual loss of the eastern territories, meant a dramatic departure from the past for Poland. For dozens of generations of Poles such cities as Grodno, Vilna or Lviv were as Polish as Warsaw, Cracow or Lublin. The Eastern Borderlands had been associated with Poland for 600 years. Even during the 19th century partitions, the borderlands were considered by the Poles to be Polish territory. Two great centres of Polish culture were situated on the areas that Poland lost - Vilna and Lviv. It is true, that on this lost territory, Poles made up $1 / 3$ of the total population. Across this entire territory, though, Poles were the biggest ethnic group, and were the main layer of the society in terms of national traditions, education and culture.

As a consequence of the loss of eastern territory and the gain of a significant compensation in the west, Poland re-emerged in a new, completely transformed territorial shape. After the enormous resettlements of the population, Poland became an ethnically homogeneous country. The overall losses and gains can hardly be precisely balanced. Wrocław, Szczecin, Gdańsk and Olsztyn became Polish cities. Besides, Poland gained a broad seacoast. The eastern boundary of Poland moved far to the west, from the dividing line established through the Treaty of Riga to - roughly - the Curzon Line. At the same time, the western boundary was moved from the line determined by the Treaty of Versailles to the course of the Odra and Nysa Łużycka Rivers. For these reasons, in the assessment of the consequences of the Polish eastern boundary being established according to the Curzon Line, the comprehensive balance of territorial changes, having ultimately led to the appearance of Poland within the boundaries decided in Yalta and Potsdam, must be accounted for.

\section{References}

Alius (Abramson A.), 1945. Die Curzon-Linie. Das Grenzproblem Sowjetunion-Polen. Zurich-New York: Europa Verlag, 99 pp.

BatOWSKI H., 1979. Linia Curzona a była Galicja Wschodnia. [in:] H. Batowski. (ed.), Z polityki międzynarodowej XX wieku. Wybór studiów z lat 1930-1975, Kraków: Wydawnictwo Literackie, pp. 186-193.

Bregman A., 1974. Najlepszy sojusznik Hitlera. Studium o współpracy niemiecko-sowieckiej 1939-1941. Londyn: Księgarnia Polska Orbis, 4th edn., 160 pp.

CIEŚLAK T. (ed.), BASIŃSKI E. (elaboration), 1967. Stosunki polsko-radzieckie w latach 1917-1945. Dokumenty i materiały. Tom 1. Warszawa: Ksiqżka i Wiedza, 569 pp.

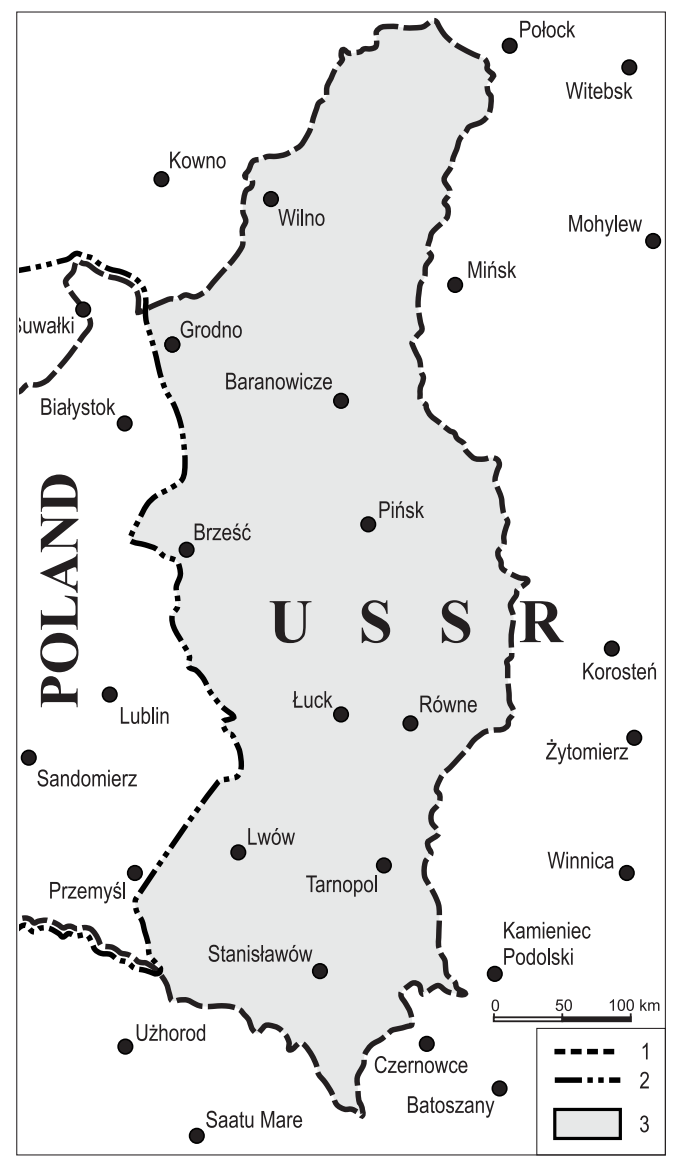

Figure 6. Eastern boundary of Poland (1921-1939 and after 1945). Signatures: 1 - eastern boundary of Poland according the Treaty of Riga (March 18th, 1921); 2 - eastern boundary of Poland according to the Polish-Soviet agreement of August 16th, 1945; 3 - territories lost by Poland to the advantage of the USSR.

Source: on the basis of Demart (2009: 112).

DAsZKIEWICZ W., Rotfeld D. (ed., translation), 1970. Teheran-Jałta-Poczdam. Dokumenty konferencji szefów trzech wielkich mocarstw. Warszawa: Polski Instytut Spraw Międzynarodowych, Ksiqżka i Wiedza, 550 pp.

Demart, 2009. Historyczny Atlas Polski. Warszawa: Demart $127 \mathrm{pp}$.

DMOWSKI R., 1947. Polityka polska i odbudowanie państwa. Tom 1-2. Hannover: s.n., 3th edn., 347+168 pp.

DYMSZA L., 1911. Sprawa chełmska. Warszawa: s.n., 120 pp.

EBERHARDT P., 1993. Polska granica wschodnia 1939-1945. Warszawa: Editions Spotkania, 223 pp.

EBERHARDT P., 2004. Polska i jej granice. Z historii polskiej geografii politycznej. Lublin: Wydawnictwo UMCS, 302 pp.

Gasiorowska-Grabowska N., Chrienow I.A. (eds.), 1961. Dokumenty i materiały do historii stosunków polsko-ra- 
dzieckich. Tom II. Listopad 1918-kwiecień 1920. Warszawa: Ksiq̨żka i Wiedza, 889 pp.

GąiorowsKa-GrabowsKa N., ChrienOW I.A. (eds.), 1964. Dokumenty i materiały do historii stosunków polsko-radzieckich. Tom III. Kwiecień 1920-marzec 1921. Warszawa: Ksiqżka i Wiedza, 676 pp.

Gilmour, D., 2006. Curzon. Imperial statesman. London: Farrar Straus Giroux, 684 pp.

KARSKI J., 1998. Wielkie mocarstwa wobec Polski 1919-1945. Od Wersalu do Jałty. Lublin: Wydawnictwo UMCS, 507 pp.

KIRKIEN L., 1945. Russia, Poland and the Curzon Line. Edinburgh: Edinburgh Caldra House, 62 pp.

KoWALSKI M., 2008. Wileńszczyzna jako problem geopolityczny. [in:] P. Eberhardt (ed.), Problematyka geopolityczna ziem polskich, Prace Geograficzne, no. 218, Warszawa: Instytut Geografii i Przestrzennego Zagospodarowania PAN, pp. 267-296.

KUMANIECKI K.W., 1924. Odbudowa państwowości polskiej. Najważniejsze dokumenty 1912-styczeń 1924. Warszawa: J. Czernecki, 782 pp.

LESZCZYCKI S., 1992. Ważyły się w 1945 roku losy Bieszczadów. Miesięcznik Ziem Górskich, vol. 3, no. 1-2, pp. 17-18.

MikOŁAJCZYK S., 1986. Polska zgwałcona. Tom 1-2. Biblioteka Obserwatora Wojennego, Warszawa: Powielarnia Puszcza Niepołomicka, 96+95 pp.

MroczKA L., 1998. Spór o Galicję Wschodniq 1914-1923. Prace Monograficzne Wyższej Szkoły Pedagogicznej w Krakowie, no. 242, Kraków: Wydawnictwo Naukowe WSP, 219 pp.
OsÓBKA-MORAWSKI E., 1992. Trudna droga. Fragmenty wspomnień. Warszawa: Tydzień Robotnika, 191 pp.

PArker J.G., 1991. Lord Curzon 1859-1925. A bibliography. Bibliographies of British Statesmen, vol. 5, New York: Greenwood Press, $124 \mathrm{pp}$.

PIsZCZKOWSKI T., 1969. Odbudowanie Polski 1914-1921. Historia i polityka. London: Księgarnia Polska Orbis, 342 pp.

PobÓG-Malinowski W., 1981. Najnowsza historia polityczna Polski. Okres 1939-1945. Gdańsk: Wydawnictwo Głos, 910 pp.

SMOGORZEWSKI K., 1944. About the Curzon Line and other lines. Free Europe Pamphlets, no. 7, London: Free Europe, $28 \mathrm{pp}$.

STANISŁAWSKA S. (ed.), 1965. Sprawa polska w czasie drugiej wojny światowej na arenie międzynarodowej. Zbiór dokumentów. Warszawa: Państwowe Wydawnictwo Naukowe, $836 \mathrm{pp}$.

WaPIŃSKI R., 1994. Polska i małe ojczyzny Polaków. Z dziejów kształtownia sie świadomości narodowej w XIX i XX wieku po wybuch II wojny światowej. Wrocław-Warszawa-Kraków: Ossolineum, $418 \mathrm{pp}$.

Wolmar A., 1945. The Crimean diktat must be annulled. Palestine: Committee of Polish Citizens' Organisations in Palestine, $15 \mathrm{pp}$.

WyszCZELSKI L., 2008. O Polsce w Wersalu. Toruń: Wydawnictwo Adam Marszałek, 114 pp.

ŻURAWSKI VEL GRAJEWSKI P.P., 1995. Sprawa ukraińska na konferencji pokojowej w Paryżu w roku 1919. Warszawa: Wydawnictwo Naukowe Semper, 128 pp.
(C) Piotr Eberhardt

(C) Geographia Polonica

C Institute of Geography and Spatial Organization,

Polish Academy of Sciences, Warsaw, 2012
Article first received • March 2012 Article accepted • July 2012 
http://rcin.org.pl 